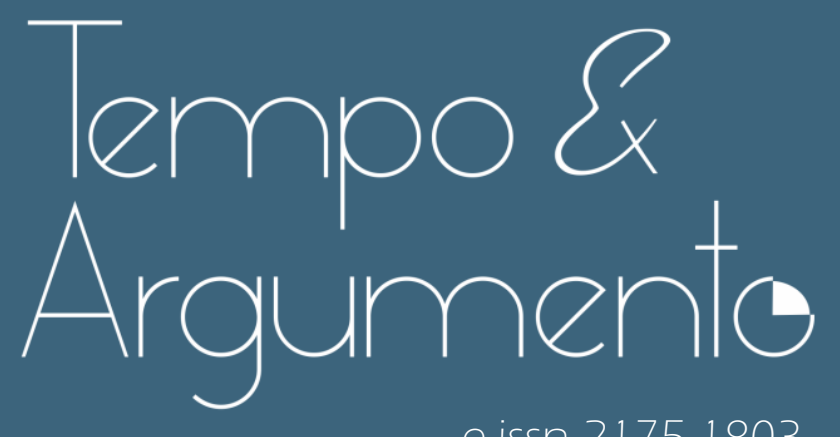

e-issn 2175-1803

Quando o mal é grande e sem remédio radical, tomamos remédios improvisados - a industrialização do cinema e as origens da organização do público na França (1895-1914)

- Luiz Felipe Cezar Mundim

Doutor em História pela Universidade Federal do Rio Grande do Sul (UFRGS) e pela Université Paris 1 Panthéon-Sorbonne. Estágio Pós-Doutoral em História Social na Universidade Estadual de Campinas (UNICAMP) com bolsa da Fundação de Amparo à Pesquisa do Estado de São Paulo (FAPESP).

Campinas, SP - BRASIL lattes.cnpq.br/7860551363238607 luizmundim@gmail.com

(iD) orcid.org/0000-0003-0684-7918

Para citar este artigo:

MUNDIM, Luiz Felipe Cezar. Quando o mal é grande e sem remédio radical, tomamos remédios improvisados - a industrialização do cinema e as origens da organização do público na França ( 1895-1914). Tempo e Argumento,

Florianópolis, v. 13, n. 32, e0203, jan./abr. 2021.

doi http://dx.doi.org/10.5965/2175180313322021e0203

Recebido: 12/12/2019

Aprovado: $21 / 12 / 2020$ 


\title{
Quando o mal é grande e sem remédio radical, tomamos remédios improvisados - a industrialização do cinema e as origens da organização do público na França (1895-1914)
}

\begin{abstract}
Resumo
A expansão mundial da sala de cinema comercial entre os anos de 1908 e 1914 foi notável, e incontestável. Neste artigo, procuramos demonstrar que essa expansão, ou industrialização do cinema, desenvolveu-se em lógica empresarial que buscava explorar ao máximo a reprodutibilidade do filme e a multiplicação do número de espectadores. Surgiu, daí, a primeira ideia de público de cinema. A formação desse público passou, ainda, pela naturalização do modo de representação do cinema clássico, com seus temas e formatos que instituíram a passividade nos indivíduos diante dos filmes. Entretanto, a posição do movimento operário francês do começo do século XX, diante do cinematógrafo, demonstra que a criação desse modo de representação não foi sentida passivamente. A convivência social dos operários nos primeiros anos de existência do cinema apresentou outra forma de relação com a imagem em movimento, diversa da comercial, apontando na categoria de "público" uma escala de análise na história contemporânea alternativa às noções consagradas de "massa" ou "espectador".
\end{abstract}

Palavras-chave: Público de Cinema. História. Movimentos sociais.

\section{When evil is great and without radical medicine, we take improvised medicines - in the cinema's industrialization the origins of public organization in France (1895-1914)}

\begin{abstract}
The worldwide expansion of the commercial cinema theater between 1908 and 1914 was remarkable, and undeniable. In this paper, we seek to demonstrate that this expansion, or industrialization of cinema, developed in business logic that sought to explore as much as possible the reproducibility of the film and the multiplication of the number of spectators. Then came the first idea of the modern public. The formation of this public also went through the naturalization of the mode of representation of classical cinema, with its themes and formats that instituted passivity in individuals before the films. However, the position of the early-twentieth-century French working class movement vis-à-vis the cinematographer demonstrates that the creation of this mode of representation was not passively felt. The social coexistence of the workers in the first years of cinema's existence presented another form of relationship with the moving picture, different from the commercial one, pointing in the category of "public" a scale of analysis in contemporary history alternative to the consecrated notions of "mass" or "spectator".
\end{abstract}

Keywords: Public of Cinema. History. Social Movements. 
Ele não pensava no que ele queria, e sim naquelas coisas às quais era levado a pensar. O que era, então, a espontaneidade, a liberdade de pensamento? o que era a vontade? E ele, quem era ele, se não uma máquina pensante, que se movia de acordo com a vontade do seu mecanismo e do qual era apenas o espectador?

Edmondo De Amicis. Cinématographe Cérébral (2008, p. 130, tradução nossa)

O cinema, mesmo tendo surgido em meio à exploração comercial do mercado de atrações e entretenimento urbano do final do século XIX, não firmou naturalmente sua fruição apenas nos moldes comerciais, nem centrada na espectação do filme. O processo de domesticação do público para o espetáculo cinematográfico, que testemunhou em paralelo experiências antagônicas não comerciais, tais como as do cinema educador, do cinema católico e do cinema militante no começo do século XX, expõe a alternativa histórica a outro tipo de controle do cinema que não apenas o comercial. A organização do acesso e da distribuição dos filmes ao público deu origem a diversas formas institucionais nos termos de exibição: a sala de cinema comercial, forma principal do cinema instituição; o cinema ambulante; o cinema militante; o cinema escolar; o chamado cineclube, a partir da década de 1920, entre tantos outros.

A sala de cinema comercial, a olhos vistos, se expandiu mundialmente de maneira massiva e incontestável, apagando o indivíduo não apenas na relação de espectação do filme, mas, também nas formas de compreensão histórica desse fenômeno incontornável do tempo presente que é a representação pela imagem em movimento. Pretende-se apresentar com brevidade, neste artigo, o seguinte percurso: a consolidação dessa expansão, ou industrialização do cinema - que teve como principal espaço a França dos primeiros anos do século XX, e só posteriormente os Estados Unidos, a partir de 1914; e o surgimento, daí, da

\footnotetext{
'Sobre os cineclubes ver, por exemplo, MACEDO, 2010, p.78 que, seguindo o artigo de 1993 de Laurent Mannoni, procura identificar e atribuir à experiência do Cinema do Povo o primeiro espaço institucional de ocorrência de um cineclube. (Ver: MANNONI, Laurent. 28 octobre 1913: création de la société 'Le Cinéma du Peuple'. 1895, Revue d'histoire du cinéma, Paris: Association française de recherche sur l'histoire du cinéma, p. 100-107, oct. 1993.)
} 
primeira ideia de público de massa de que falam os teóricos da indústria cultural, ou público moderno, termo mais adequado para a abordagem que se propõe². Em seguida, será colocada em relevo a posição do movimento operário francês do começo do século XX diante do cinematógrafo. Esse aspecto do momento final do período denominado primeiro cinema (que compreende os anos de 1895 a 1914, a ser descrito na primeira parte do artigo) demonstra que a criação desse modo de representação não foi sentida passivamente.

O objetivo é observar na convivência social dos operários, nos primeiros anos de existência do cinema, uma outra forma de relação com a imagem em movimento, diversa da comercial, apontando na categoria de "público" uma escala de análise na história contemporânea alternativa às noções consagradas de "massa" ou "espectador". É nessa relação, entre pessoas e filmes, nas concepções e categorias com que o público de cinema é estudado na história, que pretendo direcionar a reflexão. Essa reflexão nos parece pertinente, na medida em que pode apontar para uma abordagem metodológica a partir do diálogo com uma larga tradição na teoria da história, que remete à tensão entre sujeito e estrutura e que será descrita brevemente a seguir.

\section{A ideia de público como questão de escala}

Existe a ideia, em estudo da historiadora Vanessa R. Schwartz, de que para entender o modo da recepção cinematográfica como uma prática histórica, seria essencial localizar o cinema no campo das formas e práticas culturais associadas à florescente cultura de massa do fim do século XIX. O argumento se baseia no fato de que não seria "mera coincidência" que, além do interesse das pessoas pela realidade, as atividades analisadas tivessem como alvo grandes grupos de pessoas nos quais a mobilidade pela cidade provocava alguns dos efeitos realistas dos espetáculos. Para a autora, essas práticas revelam que "a flânerie não foi simplesmente privilégio do homem burguês, mas uma atividade cultural

\footnotetext{
2 Por público moderno entendemos a formação dos variados grupos de pessoas marcados pela relação de espectação na modernidade, em que há sempre, em alguma instância, a intermediação do mercado cultural, e em que as obras artísticas e culturais são tidas como produtos. No caso do cinema, e dos espetáculos em geral, essa relação se dá principalmente, mas não apenas, pelo instituto do ingresso.
} 
para todos os que participavam da vida parisiense" e que, portanto, "esse tipo de flânerie para as massas aponta para o nascimento do público, porque é necessariamente na multidão que se encontra o espectador cinematográfico". (SCHWARTZ, 2001, p. 436)

Nicole Brenez, historiadora do cinema rebelde das primeiras décadas do século XX, evoca no prefácio ao livro Cinema e Anarquia, de Isabelle Marinone, a passagem da Dialética do Esclarecimento em que Adorno e Horkheimer falam sobre o caráter eminente da função do riso, como meio fraudulento, de ludibriar a felicidade na indústria cultural e, portanto, no cinema. Os frankfurtianos em questão asseveram que "Fun é um banho medicinal, que a indústria do prazer prescreve incessantemente", e que "na falsa sociedade, o riso atacou - como uma doença - a felicidade, arrastando-a para a indigna totalidade dessa sociedade". (ADORNO; HORKHEIMER, 1985, p. 131-132). Foi pela via da totalidade que esses autores encontraram nas definições de massa e espectador o aporte para os estudos que deveriam ser realizados no âmbito da teoria crítica da cultura.

O que não pode ser esquecido, entretanto, é que o cinema também é capaz de produzir riso ofensivo que, conforme Nicole Brenez atenta, "conduz a explosões de uma alegria verdadeira no mundo concreto devastado pela injustiça, pelo individualismo e pelo conformismo." (BRENEZ, 2009, p. 13). Tratase de uma escolha do que se quer fazer ver ou, mais especificamente: diz respeito às estratégias de pesquisa sobre cinema e história, e não exclusivamente sobre os filmes ou sobre a recepção deles, na figura amorfa da "multidão que se encontra o espectador cinematográfico", segundo a expressão de Schwartz citada logo acima. Trata-se, em outros termos, de uma questão de escala de análise.

Inverter a tendência dos grandes conjuntos que superam a complexidade do objeto não significa cair na tentação do encanto do individual ou do excepcional, mas, sim restaurar uma visão analítica mais dinâmica da realidade social. A preocupação aqui reside em observar a agência dos atores e dos grupos sociais sem, com isso, relegar a totalidade a um mero pano de fundo. Não se trata de opor o micro e o macro de maneira estanque. "A escala não é um dado 
Quando o mal é grande e sem remédio radical, tomamos remédios improvisados - a industrialização do cinema e as origens da organização do público na França (1895-1914)

Luiz Felipe Cezar Mundim

preestabelecido, mas resulta de uma escolha estratégica que envolve a própria significação da pesquisa: o que vemos é aquilo que escolhemos fazer ver", assim chama a nossa atenção Giovanni Levi para a as implicações da reflexão sobre escala na pesquisa histórica (LEVI, 1998, p. 203). A partir dessa preocupação que o procedimento de Levi, em A herança imaterial, parece ser sempre o de inventar um contexto pertinente que leva a história do vilarejo de Santena até uma escala maior de apreensão, a do absolutismo piemontês em expansão no final do século XVII (REVEL, 2000).

O termo público, como veremos adiante, nos fornece a possibilidade de expressar a variação de escala necessária ao estudo das ações alternativas ao cinema comercial do começo do século XX, em especial as empreendidas pelo movimento operário francês, como a experiência da cooperativa Cinéma du Peuple (Cinema do Povo), pioneira em termos de organização completa do tripé cinematográfico (produção, distribuição e exibição) em meios não comerciais. O Cinema do Povo, tendo surgido em uma franca aproximação dos militantes franceses com o cinema desde 1909, quando o processo de industrialização do cinema na França já estava avançado, durou de outubro de 1913 a julho 1914. Transmitida para além de 1914, essa experiência foi, ao que tudo indica, a primeira tentativa organizada da classe trabalhadora de apropriação do cinema, tendo lançado as bases de uma nova forma de intervenção frente à hegemonia do cinema comercial ${ }^{3}$.

Outras pesquisas poderiam observar, por exemplo, as estratégias de formação de público de teatro no meio operário, expressão artística bastante difundida entre os militantes no mesmo período. É a ideia de público, diferente do conceito de espectador inserido na estrutura de entretenimento de massa, que pode recuperar a ênfase nas estratégias tanto coletivas quanto individuais,

\footnotetext{
${ }^{3}$ O Cinema do Povo pode assim ser observado na história do cinema por ter sido de fato a primeira organização plena de público, pois envolveu produção, distribuição e exibição de filmes, tudo em um circuito não comercial e voltado para a militância revolucionária. A partir da trajetória dos militantes e da análise dos filmes dessa cooperativa, é possível identificar o início do desenvolvimento de uma percepção própria do movimento operário para o modo de representação cinematográfico. Ver: MUNDIM, Luiz Felipe C. O público organizado para a luta: 0 Cinema do Povo na França e a resistência do movimento operário ao cinema comercial (18951914). 290 f. 2016. Tese (Doutorado em História) - Universidade Federal do Rio Grande do Sul; Université Paris 1 Sorbonne, Porto Alegre, 2016.
} 
Quando o mal é grande e sem remédio radical, tomamos remédios improvisados - a industrialização do cinema e as origens da organização do público na França (1895-1914)

que possibilita retomar a relação entre sujeito e estrutura em uma proposta de estudo de história do cinema .

Essa proposta de abordagem, que envolve observar as trajetórias e reinseri-las em seus contextos, implica em duas questões. A primeira diz respeito ao cinema. O cinema corresponde à construção de um modo de representação que, para alguns, já teria atingido a sua maturidade, mas, que para muitos ainda é jovem, próprio da cultura moderna, com muito a se desenvolver. Em geral, os desafios do conhecimento em relação ao cinema vêm sendo enfrentados por duas vias teórico-metodológicas: uma em que a pesquisa histórica lança mão do aparato conceitual da filosofia da estética e da teoria do cinema, centralizando a análise nos filmes; e outra, em que a pesquisa histórica busca na sociologia sua principal ferramenta interpretativa, em especial pela via da teoria crítica da cultura. Evidentemente, esses formatos não se dividem de maneira cristalina, e essa proposta de identificação entre eles tem a função principal de produzir reflexão específica sobre escala.

A outra questão deriva dessa primeira, e diz respeito à operação em escala diversa da que usualmente os historiadores do cinema lançam mão. As duas vias apresentadas se referem, a primeira ligada à teoria do cinema, a uma escala de análise bastante reduzida e de maneira geral limitada ao objeto fílmico e seus aspectos estéticos (forma e conteúdo); e a segunda, a uma escala macro e adepta ao modelo estrutural de conceitos como massa e espectador. O que se coloca aqui é que, com o uso do conceito de público, torna-se possível realizar a abordagem em uma escala que, se não é intermediária a essas duas escalas apontadas, ao menos possibilita um trabalho alternativo a elas, que busque um termo de reencontro entre sujeito e estrutura. Tal operação se dá por meio do

\footnotetext{
${ }^{4}$ A Revolta de Astor Place, envolvendo o público de teatro de Nova lorque em 1849, é um exemplo pioneiro dessa agência no campo do teatro. O documento "Relato da Terrível e Fatal Revolta no 'New-York Astor Place Opera House'” diz que o confronto entre forças policiais e a população trabalhadora, que do lado de fora do teatro protestava contra a apresentação do ator inglês William Macready, “tornou-se 'A noite do horror', pois, no dia seguinte, quando a terrível tragédia veio a ser amplamente conhecida, caiu sobre a cidade como uma mortalha funerária.” (RANNEY, 1849, p. 5). O resultado foi a morte de vinte e duas pessoas, e cerca de trinta feridas e mutiladas. Noel Burch, em La lucarne de l'infini, afirma que antes de 1850, a maior parte dos teatros nos Estados Unidos se esforçava em oferecer espetáculos que agradassem a todos os gostos, o que estava se tornando insustentável pela diversidade social nesses espaços, tendo assim a revolta um papel importante na aceleração da indústria do "show business". (BURCH, 2007, p. 122).
} 
reconhecimento do público ativo diante do mercado cinematográfico, e dos filmes a que assiste ou que produz, como foi o caso do Cinema do Povo mencionado acima.

Para apresentar melhor esses problemas, vejamos alguns casos. Dentre os autores que se enquadram na escala reduzida encontra-se, por exemplo, o historiador Eduardo Morettin. A partir da crítica à obra de Marc Ferro, Morettin busca construir os fundamentos de um estudo do cinema enquanto fonte histórica, desde que centrada no filme. Chama a atenção para o fato de que na obra de Marc Ferro existem pressupostos que separam, nos filmes, os conteúdos e o enredo dos demais componentes especificamente cinematográficos. Esse equívoco metodológico, segundo Morettin, se dá em função das dicotomias que Ferro propõe ao sustentar a análise dos filmes, como 'aparente - latente', 'visível - não visível' e 'história - contra-história'. Morettin (2007, p. 42), diz que "afirmar a possibilidade de recuperar o 'não visível' através do 'visível' é contraditório, uma vez que essa perspectiva vê a obra cinematográfica como portadora de dois níveis de significados independentes, perdendo de vista o caráter polissêmico da imagem."

A reflexão que Morettin propõe com a leitura de Ferro é a de que o uso do cinema como 'arma de combate' e a exploração de sua potencialidade na construção de uma história com o cinema, em detrimento de uma história do cinema, só podem ser concretizadas se o filme for alçado ao primeiro plano. Para tanto, o historiador deve enfrentar, enfim, a questão da análise fílmica (MORETTIN, 2007, p. 61). Esse enfrentamento não corresponde às leituras feitas da obra, como expressas nas críticas de época e nas falas do diretor, mas sim ao sentido que emerge da estrutura própria das obras. O filme possui um movimento que the é próprio, e cabe ao estudioso identificar o seu fluxo e refluxo, na medida em que se refaz o caminho trilhado pela narrativa e que se reconhece a área a ser percorrida a fim de compreender as opções que foram feitas e as que foram deixadas de lado no decorrer de seu trajeto (MORETTIN, 2007, p. 62). 
A este respeito Morettin diz:

A pesquisa documental, elucidativa para entender a trajetória de uma película, não corresponde de maneira exclusiva à contribuição dada pela história ao processo de intelecção do cinema, pois, neste caso, não estaríamos distantes de uma tradicional, porém mais acurada, história do cinema e de suas produções. Trata-se de desvendar os projetos ideológicos com os quais a obra dialoga e necessariamente trava contato, sem perder de vista a sua singularidade dentro de seu contexto. O cinema, cabe ainda ressaltar, não deve ser considerado como o ponto de cristalização de uma determinada via, repositório inerte de várias confluências, sendo o fílmico antecipado pelo estudo erudito. (MORETTIN, 2007, p. 63)

Com essas questões, Morettin se preocupa com o fato de que a ideia de narrativa enquanto prática discursiva, que tem características próprias no campo do cinema, só pode ser mobilizada através da análise fílmica.

Outra questão se impõe neste momento: se público é a ideia-chave para se analisar o período chamado primeiro cinema, em que a relação passiva de espectação ainda não havia sido naturalizada, e da mesma forma para se observar a relação do movimento operário com o cinema nesse período, por que tal abordagem não é comum? O conceito de público é assumidamente difícil de ser definido segundo alguns sociólogos. Tratado com bastante cautela, e mesmo evitado por alguns teóricos, as dificuldades começam na medida em que não é possível situar perfeitamente o objeto quando se fala em público.

Jean Pierre Esquenazi, sociólogo da comunicação, diz que “apenas há público de alguma coisa e esse de representa uma primeira dificuldade do trabalho: é preciso delimitar as situações que têm público para poder determinar este último." (ESQUENAZI, 2006, p. 5). A preocupação externada por Esquenazi relaciona-se, basicamente, com as implicações do uso da definição de público em pesquisas de caráter sociológico. São pesquisas que buscam descrever a relação de determinados grupos de pessoas com os produtos, em que se expressa unidade a um dado grupo, conforme a definição de público atribuída pelo sociólogo que faz a pesquisa.

O retrato da instabilidade do conceito são as várias definições que podem ser encontradas, o que por um lado pode levar os investigadores a preferirem 
encaminhar os estudos em escala diversa, no sentido da "sociologia da recepção" ou, mais comumente, na mencionada relação da teoria crítica da cultura entre indústria cultural e massa. O cinema teria, afinal, a característica desde a sua origem do aparente anonimato daquele que assiste ao filme e, por conseguinte, de uma ininteligível massa de indivíduos que se postam passivamente diante da velocidade das sequências de imagens. Falar sobre essa massa só seria possível pela via de uma percepção geral, ou generalizada, mediante determinados fundamentos ou características socioeconômicas.

Essa perspectiva, que não é exclusiva da teoria crítica, se formou concomitante à própria evolução da relação entre as pessoas e os filmes, que coincide com o domínio dos estudos com viés funcionalista. Uma socióloga alemã, em 1914, já descrevia a situação fílmica por esse olhar:

O cinema e o seu espectador são ambos os produtos típicos da nossa época caracterizada pela ocupação constante e por um estado nervoso de agitação. O homem que, ao longo do dia, está sob tensão em seu trabalho, não se libera desse curso, mesmo quando quer se recuperar. Num curto espaço de tempo, eventualmente, ele procura no cinema um entretenimento e uma diversão, e já pensa nos meios de preencher as próximas horas. Entrar em uma obra de arte, drama, peça musical ou teatral, requer um lazer seguro de si e uma tensão da vontade. O cinema não exige tal concentração. Age com meios tão poderosos que, mesmo os de nervos amaciados, se excitam; e a rápida sucessão dos acontecimentos, a confusão das coisas mais variadas, não permitem que o tédio entre. (ALTENLOH, 2008, p. 318, tradução nossa)

As asserções de Emilie Altenloh compõem uma tese, publicada na Alemanha, que é, em si, a primeira obra de sociologia do cinema e seu público. Altenloh desenvolveu sua pesquisa a partir de um questionário feito em Mannheim, cidade em que sete mil e 500 habitantes (de 204 mil) iam toda noite ao cinema. De 1912 a 1913, a pesquisadora conseguiu respostas de dois mil e 400 espectadores. Com essa base empírica, a autora construiu os elementos do que seria o paradigma da teoria da espectação. Entretanto, é importante destacar, essa é uma percepção de 1914, quando o cinema já havia se instituído não apenas como opção de lazer singular, separado das feiras e cafés, mas, também como narrativa com linguagem própria. Tornou-se, afinal, mais fácil enquadrar um 
fenômeno cultural aparentemente novo a uma dada explicação social preexistente, o que torna a relação entre as pessoas e o novo meio de comunicação, que era o cinema, em mecanismo fechado em si.

Voltando à definição de Esquenazi, encontramos uma tentativa em aproximar a sociologia das manifestações em si. O autor, ao percorrer as diversas definições clássicas, observa particularmente a concepção em que o público é encarado como um conjunto de consumidores, característica própria do funcionalismo e da sociologia crítica das indústrias culturais. O autor procura alertar para o fato de que, nessas abordagens, o objeto/manifestação a que o público se vincula não desempenha qualquer função, circunscrevendo-se a um produto industrial (ESQUENAZI, 2006, p. 29).

Esquenazi aponta para uma questão metodológica vinculada à definição de público que deve ser levada em consideração. Em suas conclusões considera que, pelo fato de ser fugidia a noção de público, cabe ao pesquisador a atribuição dos traços do conceito, conforme suas orientações e seus centros de interesse. Essa reflexão em torno do público tem como estímulo a percepção de um fenômeno contemporâneo da reunião de indivíduos, ou grupos organizados, em que há predomínio da crítica e da reflexão. Os grupos produzem esse conhecimento com a característica de ser direcionada a uma experiência comum. O indivíduo no público, a partir dessa reflexão, não perde a faculdade de crítica e autocontrole, ao contrário do que é disposto nas teorias da multidão e das massas; nem tampouco se torna refém da ampla determinação do discurso cinematográfico dos filmes.

Os relatos dos participantes das sessões cinematográficas ambulantes do militante anarquista, Gustave Cauvin, pelo interior da França entre os anos de 1910 e 1913 com filmes da Pathé, ou os relatos das festas do Cinema do Povo, por exemplo, denunciam essa dupla possibilidade de identificação do indivíduo e da coletividade que assiste ao filme (MUNDIM, 2018). Para além da espectação passiva da sala comercial, há a exibição feita para estimular a participação crítica do público.

O público de cinema, tal como procura-se apresentar aqui, se constituiu nas experiências de organização da luta pela hegemonia do controle dos meios 
de produção - incluindo o domínio do modo de representação - e de circulação da reprodução simbólica da realidade, matérias da obra cinematográfica. Foi a partir das trajetórias individuais e coletivas dos militantes do movimento operário que esse público se constituiu. Entretanto, para que essa perspectiva de público mais autônomo seja definida, faz-se necessário retomar uma breve história da formação do próprio público de cinema e da industrialização do cinema.

\section{O público de cinema: os espetáculos de atração e o primeiro cinema (1895-1914)}

O que conhecemos como "instituição cinema", que compreende a sala fechada, escura, com sessões regulares de filmes, única atração daquele espaço, veio a se disseminar apenas a partir de 1908-1909. Antes disso, não é possível falar em "público de cinema", e tampouco em "espectador de cinema". Da mesma forma, não há como falarmos em um tipo natural de fruição das pessoas em relação aos filmes. Se tomarmos os relatos de quem assistia a filmes antes disso, teremos uma grande diversidade de reações e descrições do objeto fílmico, que nem sempre era o principal foco do público. O indivíduo espectador, em si, poderia ter as mais diversas reações, e a programação, mesmo nos ambientes comerciais, eram alteradas a cada apresentação.

No romance McTeague de 1904, o escritor americano Frank Norris (18701902) descreve uma cena que se passa no Orpheum Vaudeville, para onde o personagem McTeague leva a namorada e a mãe dela para assistirem a diversas atrações, dentre elas as "imagens que se movimentam". A cena tem particular interesse, tanto pela ambientação e situações vividas pelos personagens naquele espaço, quanto pelo aspecto estético que remetem a outro autor a quem Norris era comparado, Zola. Vejamos como a cena é descrita, resumidamente:

As pessoas entraram e tomaram seus lugares. [...] As luzes estavam todas apagadas, os guardas estavam em pé sob as galerias em grupos, o auditório vazio ecoando a conversa barulhenta. Ocasionalmente, um garçom com sua bandeja e avental branco limpo passeava de um lado para o outro do corredor. Bem diante deles estava a grande cortina de ferro do palco, pintada com todos os tipos de anúncios. [...] 
A orquestra tocou com força na abertura, terminando subitamente com um grande floreio de violinos. [...] Então a orquestra tocou uma batida rápida, e a cortina subiu em um interior decorado com duas cadeiras vermelhas e um sofá verde. Uma garota de vestido azul curto e meias pretas entrou às pressas e começou a espanar as duas cadeiras. Ela estava bastante malhumorada, falando muito rápido, renegando o "novo inquilino". Parecia que este nunca havia pagado seu aluguel; que era dado a atrasos. Então ela desceu para a ribalta e começou a cantar com uma tremenda voz, rouca e achatada, quase como a de um homem. (NORRIS, 1904, p. 96-107, tradução nossa)

Em seguida, são apresentadas duas cenas teatrais cômicas, uma atração musical, uma de acrobacias, e uma cantora antes do intervalo, de quinze minutos. Ao voltarem aos seus lugares, mais uma atração com um desenhista, e a noite segue:

O salão ficou muito quente, e a fumaça de inúmeros charutos deixou os olhos espertos. Uma espessa névoa azul pairava sobre as cabeças da plateia. O ar estava cheio de cheiros variados - o cheiro de charutos obsoletos, cerveja barata, casca de laranja, gás, pó de sachê e perfumaria barata. [...]

o kinetoscópio tirou de todos o fôlego.

"O que eles farão a seguir?" Observou Trina, espantada. "Não é maravilhoso, Mac?"

McTeague ficou impressionado.

"Olhe aquele cavalo mexer a cabeça" - ele gritou empolgado, bastante empolgado. "Veja o teleférico chegando, e o homem atravessando a rua. Veja, aqui vem um caminhão. Bem, eu nunca vi isso em toda a minha vida! O que Marcus diria sobre isso?"

"É tudo um truque!", Exclamou a Sra. Sieppe, com repentina convicção. "Num sou boba; iss' daí é nada mais qu'um truque."

"Bem, é claro, mamãe", exclamou Trina, "É...

Mas a Sra. Sieppe levantou a cabeça.

"Eu sou velha demais para ser enganada", ela persistiu. "É um truque." Nada mais poderia ser extraído dela do que isso.

A multidão ficou até o final do show, muito embora o kinetoscópio fosse o último número, porém único no programa, e a metade da plateia saiu imediatamente depois. [...]

No caminho de casa, eles discutiram a performance.

"Eu... eu gostei mais dos yodlers."

"Ah, a solista foi a melhor - a mulher que cantou aquelas músicas tristes."

"Aquela lanterna mágica não... não é maravilhosa?! Para onde as figuras se moviam? Maravilhosa... ah, maravilhosa!” (NORRIS, 1904, p. 96-107, tradução nossa)

No enredo, a desventura do dentista McTeague, filho de operários mineiros, que desposa Trina apenas para se apossar de uma pequena fortuna que ela havia adquirido, parece exprimir o desencontro entre o sonho americano da conquista 
do oeste e as contradições de uma cultura corroída pelos vícios que acompanham o capitalismo e a modernidade. Segundo Paul Young, Norris caracteriza a aparição do "kinetoscópio" em McTeague como uma assombração, porque reconhece a novidade das imagens em movimento, mas as relega ao papel de um "desvio" da vida real, um papel para o qual os romances nunca poderiam se inclinar. De fato, a atração com imagens em movimento no teatro Orpheum Vaudeville deixa McTeague e seus companheiros impressionados, porém, nem tão a mais quanto os outros números. Nesse sentido, Young irá dizer que o cinema, para Norris, ofereceria nada além de uma reprodução mecânica da realidade visível, sem a qualidade de esclarecer o espírito da época, tal como o romance teria. O público, barulhento e pouco atencioso, só estava ali para se estimular e se divertir (YOUNG, 2007, p. 645-688).

A descrição de Norris nos fornece, entretanto, alguns elementos a mais que nos interessam. Trata-se, evidentemente, de uma representação da experiência inicial com os filmes. E é nessa experiência inicial, ao observarmos a ausência quase total de um comportamento obediente e individualizado diante do filme, que consideramos a origem desprovida de um regimento naturalizado da sua fruição. Todos ficam impressionados diante dos filmes, e nem por isso o público se faz massa de espectadores passivos diante das imagens em movimento. Norris descreve esse público - que na narrativa sabemos ser composto principalmente pela classe trabalhadora urbana - por sua experiência direta com o cinema. Há uma série de elementos psicológicos que correspondem às reações de cada personagem diante dos filmes a partir da sua experimentação.

O cinema, em seu aparato mecânico primário, foi criado nas fábricas e laboratórios de empresários como Thomas Edison, os irmãos Lumière e tantos outros, sendo testado imediatamente no mercado, com os pennyarcades ${ }^{5}$ ou as projeções pagas (MACEDO, 2010, p. 78). Sobre a comemoração do surgimento do cinema, Tangui Perron (1995, p. 21) destaca o aspecto comercial da nova instituição: "Jean-Luc Godard tem razão em dizer que, de fato, festejamos a

\footnotetext{
Os pennyarcades, bem conhecidos na história do primeiro cinema e anteriores ao cinematógrafo, eram máquinas como arcades que recebiam moeda pela projeção individual, levando-se o rosto ao visor, de filmes produzidos pelos aparelhos kinetoscópios, ou cinetoscópios, de patente Edison.
} 
exploração do cinema, a primeira sessão paga, e não a invenção da câmera, da película, ou mesmo do espetáculo cinematográfico."

O cinema dos primeiros 20 anos desde o seu surgimento foi observado como um conjunto de desajeitadas tentativas de se chegar a uma forma de narrativa, intrínseca ao próprio cinema (COSTA, 2006, p. 22). Ainda é possível observar os traços desse tipo de preconcepção, perpetuada no senso comum das reações de negação e escárnio diante de exibições de filmes desse período. Historiadores deram ênfase à leitura do ponto de vista evolutivo, observando o trabalho dos pioneiros do cinema como experimentações que os levariam aos princípios do que viria a ser chamado de "linguagem cinematográfica"6. Em função dessa perspectiva, o cinema produzido nesse período foi denominado, em geral, como "cinema primitivo", ou mesmo "pré-cinema".

Foi na década de 1970 que pesquisadores começaram a questionar esses juízos, procurando entender o período dos primeiros filmes não como "précinema”, mas como um cinema diferente do que viríamos a reconhecer posteriormente como "natural”. A conferência "Cinema 1900-1906" em Brighton, na Inglaterra em 1978, realizada pela Federação Internacional dos Arquivos de Filmes (Fiaf), possibilitou pela primeira vez uma discussão sistemática e coletiva sobre os primeiros filmes. A partir de Brighton, as pesquisas sobre o período se multiplicaram, e chamaram a atenção para a importância do entendimento dos filmes em seu contexto específico. Convencionou-se então, entre vários autores, denominar o cinema daquela fase como Primeiro Cinema (COSTA, 2006, p. 23).

O debate em torno da nomenclatura não se esgota facilmente. Noel Burch, por exemplo, ainda que seja um dos historiadores do cinema que tenha lançado outro olhar sobre o cinema dos primeiros tempos, dando ênfase à historicidade da formação do discurso e do público, insiste no uso do termo "cinema primitivo". Defende que de fato tratava-se de um cinema pouco refinado, e até grosseiro, tendo como referência as normas contemporâneas nos países industrializados (BURCH, 2007, p. 8, tradução nossa). A polêmica tem um fundo político, e o

\footnotetext{
${ }^{6}$ Dentre as obras históricas que abordam o momento inicial do cinema com esse caráter evolutivo destaca-se, por exemplo, Georges Sadoul e seu clássico História do Cinema Mundial - Das origens a nossos dias, de 1963. Ver: SADOUL, Georges. História do cinema mundial: das origens a nossos dias. Livraria Martins Editora, São Paulo: 1963. 2 v.
} 
principal alvo de Burch é a disputa pela perspectiva de análise em torno da transição do discurso cinematográfico durante o primeiro cinema, do atrativo ao narrativo, que se iniciou em 1904, na França.

O chamado primeiro cinema trata do momento em que se constituiu o que Burch denomina de Modo de Representação Institucional. Esse modo de representação é ensinado e perpetuado como natural e, portanto, internalizado em todos desde jovens, tal como uma competência linguística, graças à experiência fílmica. A apreensão enquanto “modo" se dá em detrimento do uso do termo "linguagem", para que seja evitada a confusão com a ideia de "línguas naturais" em Bakhtin. O modo não é aristocrático e nem neutro, e não produz sentido por si mesmo, uma vez que o sentido que produz está diretamente ligado ao lugar e à época em que foi desenvolvido: o ocidente capitalista e imperialista do primeiro quarto do século XX. Por essa genealogia, Burch nota que o modo de representação foi uma experiência apresentada universalmente de maneira muito precoce nas sociedades industriais. A intenção do autor é, ao se voltar a esse período, mostrar que o fenômeno do cinema não é natural, mas sim um produto da história: "milhões de homens e de mulheres que aprendem a ler e a escrever 'suas cartas', aprendem apenas a ler as imagens e os sons, e recebem, portanto, os seus discursos apenas como algo 'natural'”. (BURCH, 2007, p. 9, tradução nossa).

Está longe das nossas pretensões a de recriar o cenário rico e diverso que foi o primeiro cinema (1895-1914) em todo o mundo. As pesquisas nessa área vêm se proliferando e demonstrando o que antes pouco se sabia: os dados são vastos, cada país produziu relações econômicas e de público diversas com o cinema, e a produção de filmes foi muito grande, da qual pouco se tem acesso até hoje. Entretanto, de um dado desse processo não se tem dúvida: o cinema se formou instituição, primeiro, na França, e estabeleceu-se com mercado relevante na economia capitalista, de maneira definitiva, nos Estados Unidos. Ao mesmo tempo, constituiu ferramenta e produto incontornáveis na luta ideológica contemporânea. Sendo assim, quais teriam sido as condições em que se deu a formação do mercado, e do espaço, de exibição do cinema? 
No período que compreende 1895 e 1907, o cinema nos Estados Unidos se compunha na maior parte de exibições itinerantes e montadas em espaços tradicionalmente voltados para o entretenimento público que possibilitassem de alguma forma sua exploração comercial, tais como feiras, parques de diversão, quermesses, vaudevilles e cafés (HERZOG, 2002, p. 51-54, tradução nossa). O lugar fixo e exclusivo para projeções foi sendo criado aos poucos, pela própria instituição cinematográfica, na medida em que consolidava uma prática economicamente estável (MENOTTI, 2007, p. 2).

Para esclarecer melhor este aspecto da relação do público com o espaço de projeção, convém uma rápida menção ao artigo Arquitetura da Espectação, de Gabriel Menotti. Nele, o autor aponta que os espaços de exibição cinematográfica foram alterados ao longo dos anos a partir de determinações econômicas, e de forma a conjugar a experiência do filme projetado a um modelo de consumo que fosse o mais lucrativo possível (MENOTTI, 2007, p. 1). Essa adequação se estruturou no progressivo direcionamento da atenção da audiência e restrição do comportamento, que culminarão nos anos $50 \mathrm{com}$ a imposição arquitetônica da chamada situação cinema. A situação cinema, segundo Hugo Mauerhofer, é uma experiência específica de consciência, em que se altera a sensação de tempo e de espaço, possibilitada pelo isolamento mais completo possível do mundo exterior e de suas fontes de perturbação visual e auditiva, buscando ao máximo o estado passivo do espectador (MAUERHOFER, 1983, p. 375-377).

Conforme Menotti destaca, no começo do primeiro cinema "a experiência cinematográfica não era apenas contaminada, como em grande parte definida, pela organização do lugar em que a projeção se instalava e pelo comportamento tradicional de seus frequentadores" (MENOTTI, 2007, p. 2). Menotti diz que a fruição desse cinema não dependia, portanto, de superpercepção e submotricidade - termos do teórico do cinema Christian Metz que remetem à situação cinema. Dependia em grande parte da dinâmica de consumo do filme, que era vulnerável a diversas influências, em que os filmes podiam ser vistos

\footnotetext{
${ }^{8}$ As vaudevilles eram espaços que compreendiam o gênero de entretenimento predominante nos Estados Unidos de fins do séc. XIX, até por volta da década de 1920, reunindo várias atrações em um mesmo lugar.
} 
diferentemente e tinham uma ampla gama de significados, construídos a partir da habilidade do exibidor e de sua equipe, e do diverso contexto social em que eram exibidos (MENOTTI, 2007, p. 2-3).

Flávia Cesarino Costa, que também se concentra no caso norte-americano, denomina esse período, dentro do primeiro cinema, como "Cinema de Atrações" [1894-1906-7], e que antecede ao "período de transição" [1906-1915]. A divisão proposta por Costa, que é baseada na tradição supracitada dos estudos de história do cinema a partir da década de 1970, se dá com o objetivo intrínseco da ênfase no desenvolvimento da "linguagem cinematográfica". A transição de que a autora fala tem como características básicas principalmente o estabelecimento das salas voltadas exclusivamente à exibição cinematográfica, em especial as chamadas Nickelodeons; e a progressiva criação da narrativa cinematográfica, que toma forma na medida em que cresce a demanda por filmes de fiç̧ão cada vez mais dotados de uma "linguagem" que os tornasse sustentáveis e compreensíveis para o público (COSTA, 2006, p. 25-28).

Os chamados nickelodeons, vocábulo que remete à palavra grega para teatro e à moeda correspondente ao valor do ingresso (cinco centavos de dólar), importaram a postura livre e ativa do público dos vaudevilles. Esses espaços eram tipicamente pequenos, pouco confortáveis, e instalados em armazéns e lojas adaptadas. O público era, em geral, a camada proletária em busca de entretenimento, favorecida pela redução das horas de trabalho (MENOTTI, 2007, p. 3).

Os nickelodeons serviam também como refúgio para a população dos guetos, em particular, os estrangeiros. Os filmes ainda não tinham centralidade na prática da projeção, posição que viriam a assumir só a partir de 1915. O que importava era escapar dos sobrados precários, da insalubridade das fábricas e conviver com o outro. Burch apresenta o argumento, por exemplo, de que o público de massa se concretizou de maneira mais efetiva nos Estados Unidos tendo como causa a grande quantidade de imigrantes. Os espetáculos deveriam ser compreensíveis, e os filmes deveriam falar por si sós, assim como as pequenas peças cômicas, truques diversos, dentre outras atrações antes apresentadas nas vaudevilles. 
Entretanto, algumas dessas descrições emprestam aos nickelodeons e ao início do cinema um caráter nostálgico e até romântico. Os elementos socializantes nesses espaços não significaram que os exibidores se propuseram a oferecer um entretenimento democrático. Pelo contrário, estavam atrás de um negócio lucrativo. Foi por necessidade que acolheram imigrantes, operários e desempregados. Tão logo se mostrou possível, buscaram controlar o comportamento da audiência e atrair a classe média (MENOTTI, 2007, p. 4).

Paralelamente, e de toda forma, foram os nickelodeons que estabeleceram um padrão para a distribuição de filmes e construíram a base de um público composto por classes diversas. Em 1910, já havia cerca de 10.000 salas de exibição espalhadas por todo os Estados Unidos, criando uma demanda para cerca de 150 novos rolos de filme toda semana. A importância econômica do cinema aumentava cada vez mais (MENOTTI, 2007, p. 4).

Nota-se que foi nesse momento que os Estados Unidos deram início a sua escalada no domínio do mercado cinematográfico global. Antes de 1908, a produção de filmes norte-americana era incipiente, uma vez que a demanda era majoritariamente por filmes de atração e atualidades, quando a ficção ainda se fazia pouco presente nas salas. Os filmes exibidos eram em sua maioria franceses, produzidos na maior parte pela Gaumont, Éclair e Pathé. Foi com os nickelodeons que a demanda por muitos filmes, em especial os de ficção, passou a ser premente. Começou a ser organizada, então, uma nova forma de organização da produção cinematográfica naquele país.

Charles Musser indica, em artigo comparativo entre a indústria do cinema na França e nos Estados Unidos, que a inspiração para esse novo sistema foi o modelo dos irmãos Pathé na França no período imediatamente anterior, de 1903 a 1906 (MUSSER, 1997, p. 63-80, tradução nossa). Numa rápida checagem em registro de publicação associativa de 1908, por exemplo, a Pathé contava 47 produções de filmes contra apenas 20 da Vitagraph, e 9 da Edison ${ }^{9}$. Nesse período, a Pathé ainda desempenhava dominação e respeito internacional, a quem os americanos procuravam imitar.

${ }^{9}$ Views and Film Index. 2 may, 1908. Listagem de filmes disponíveis na p. 7 do jornal. 
A Vitagraph, empresa americana criada ainda em 1897, e importante agente nesse cenário, atingiu seu apogeu em 1907. Rapidamente a companhia se expandiu, abriu sua própria rede de distribuição em Paris e passou a colaborar com a Pathé em alguns projetos, com destaque para a publicação do jornal associativo Views and Film Index (VFI) nos Estados Unidos (MUSSER, 1997, p. 69, tradução nossa).

Conforme Musser afirma, a passagem para o modelo industrial de produção e de distribuição cinematográfica em grande escala, realizada pela primeira vez pela Pathé Frères, não se efetuou rapidamente, nem facilmente no cinema americano. A mudança veio, ou foi sentida, aos poucos pelos envolvidos no meio empresarial das produtoras. Tradicionalmente comprometidas com a colaboração protocorporativa e com a horizontalidade da produção, as produtoras resistiam à mudança do sistema.

Uma das principais características do sistema americano associativo em seu auge era o forte controle sobre as patentes e sobre as licenças de filmes, práticas estimuladas e impostas principalmente pelas empresas Edison. Em publicação da VFI, do dia 2 de maio de 1908, observa-se que os boletins dos encontros do comitê executivo da Films Service Association são enfáticos na verificação e obediência das regras, listadas resumidamente da seguinte forma:

I - Prevenir Filmes Licenciados de chegar às mãos de exportadores fora da nossa Associação;

II - Prevenir sublocação de filmes licenciados;

III - Prevenir o aluguel de Filmes Licenciados abaixo do valor mínimo estipulado. (MCDONALD, 1908, p. 5, tradução nossa)

Assinavam o boletim, as companhias que mantinham a associação: Edison, Essanay, Kalem, Sigmund Lubin, George Mélies, Pathé Frères, Selig Polyscope e Vitagraph. A julgar por esses boletins, e por outras notas nessa mesma publicação da VFI, as mudanças que estavam em curso ainda pareciam de difícil aceitação para os envolvidos, que se espantavam e desconfiavam de uma visita de Charles Pathé aos Estados Unidos: "Todo mundo no mercado está se perguntando qual o significado deve estar atrelado à visita de Charles Pathé, que chegou a este país na última semana. O Sr. Pathé se recusa completamente a falar ao jornalista, mesmo esse escriba estando apto a conversar em francês. [...]" (WHAT PATHÉS..., 1908. p. 3, tradução nossa). 
Numa conjuntura em escala não tão maior, a julgar pelo período de 19071909, as unidades mais produtivas do meio cinematográfico norte-americano passaram, por força de demanda de mercado exibidor, de um conglomerado de estruturas de produção - com certa autonomia, baseadas no princípio de associação - a um sistema bem mais próximo do empresarial, verticalizado e semelhante ao modo de organização da produção empreendido pela Pathé a partir da França. A característica do novo sistema passou a ser uma organização centralizada, no qual um produtor supervisionava certo número de unidades de produção, tal como havia sido desempenhado por Ferdinand Zeca na Pathé. Os filmes deveriam ser produzidos em maior quantidade e com maior padrão de qualidade técnica.

Na relação com o público, o ambiente dos nickelodeons continuava a espantar ricos e classe média, tanto em função da insalubridade dos locais quanto pela aversão às pessoas que lá frequentavam. Assim, algo ainda precisava ser mudado nos espaços de exibição, e a mudança começou a se efetivar com a higienização do produto cinematográfico (MENOTTI, 2007, p. 4-5).

Além de tornar o filme um produto inofensivo, era necessário sofisticá-lo e direcionar a atenção do público só a ele. Sofisticado, o filme ganha um incremento comercial, o que causou uma reorganização da indústria cinematográfica. O surgimento do melodrama no cinema, fruto de uma complexificação do drama, criou nova disposição cognitiva na sala de exibição, obrigando o público a focar-se no filme para compreender o que se passava (MENOTTI, 2007, p. 5).

Consoante com as demais estratégias de "higienização" do espaço de exibição, essas mudanças buscavam torná-lo um lugar familiar e de comportamento retido. As estratégias visavam à anulação da presença do outro, tanto pela repressão do comportamento leviano quanto pela eliminação de todos os sentidos que não serviam ao consumo do filme.

A França deu o seu exemplo: em agosto de 1908, Paris já tinha sua lei municipal, de competência da prefeitura de polícia, concernente aos teatros com regulamentação detalhada e específica para os cinemas. Além de todas as medidas de segurança, controle da qualidade do ar e da luz, aquecimento, 
serviços médicos e observância mínima das condições de trabalho que as demais salas de teatro deviam seguir, os cinemas deveriam seguir normas estritas de segurança contra incêndio, de observância dos horários e filmes divulgados para as sessões e, determinados comportamentos do público que antes eram considerados normais, agora também deveriam ser proibidos:

ART. 218. - É proibido fumar no interior dos estabelecimentos, exceto autorização especial expedida a determinado estabelecimento para áreas específicas no local.

[...] ART. 220. - É proibido perturbar sistematicamente a apresentação ou impedir os espectadores de ver ou de ouvir o espetáculo de qualquer forma que seja. Qualquer pessoa, nomeadamente, cujo chapéu seja um obstáculo à vista dos espectadores posicionados atrás dela, será instada a cumprir requisição de cessar a perturbação que terá ocasionado. (LAURENT; LEPINE, 1911, p. 52, tradução nossa)

Essas mudanças levaram a um formato do espaço de exibição marcado pela separação entre a sala de projeção e a convivência social, ao mesmo tempo em que os produtores apelavam para filmes que se aproximavam em forma e em duração das peças de teatro. Nesse contexto os exibidores buscaram, por fim, atrair o público de maneira diferenciada, com o uso de carpetes luxuosos e mordomias correlatas, dando início à era dos movie palaces nos Estados Unidos.

A emulação do espetáculo teatral, com a reprodução do ambiente luxuoso e a provocação da passividade do espectador, se completava na nova representação do enredo fílmico inspirado no individualismo dos romances, no maniqueísmo, no sentimentalismo, e em certo moralismo e dramaticidade do teatro popular. Surgiu, então, o melodrama como principal estrutura narrativa dos filmes, envolvendo os pilares do herói, da família e da virtude em filmes que deveriam contar histórias completas do começo ao fim, sem necessidade de suportes explicativos externos ao filme, como os narradores das sessões ${ }^{10}$.

Apenas filmes maiores poderiam suprir a demanda desse sistema. Assim, a necessidade do padrão de qualidade envolvido na complexa produção de um

\footnotetext{
Essa atribuição ao conceito de melodrama remete à formulação dada por Ismail Xavier, recorrente em toda a sua obra. Ver, por exemplo: XAVIER, Ismail. O discurso cinematográfico: a opacidade e a transparência. 3. ed. São Paulo: Paz e Terra, 2005; e O olhar e a cena: melodrama, Hollywood, cinema novo, Nelson Rodrigues. São Paulo, Cosac \& Naify, 2003. Ver também sobre a ideia de "literarização" do filme, a obra: PAECH, Joachim. A institucionalização e a literarização do filme. Revista Contingentia, v. 5, n. 1, p. 99-114, maio 2010.
} 
filme de mais de 250 metros (acima de 10 minutos), apontou para o sistema organizativo de verticalidade da gestão da produção. A fórmula parecia evidente, uma vez que os franceses haviam passado a produzir filmes maiores já havia alguns anos. Unidades de produção foram criadas para suprir a demanda e passaram a trabalhar com gêneros específicos, como filmes históricos, comédias, romances ou dramas, no que seria muito em breve o sistema de gêneros de filmes hollywoodiano.

O empresário Adolph Zukor se destacou nesse momento com a criação da Famous Players-Lasky, a Paramount. Ao entrar no mercado em 1912, a Famous Players iniciou suas atividades voltadas à produção de longas, sendo a primeira a produzir um filme neste formato: The Squaw Man lançado em 1914, sob a direção de Oscar Apfel e Cecil B. DeMille. Concentrou-se em atores e atrizes conhecidos e asseverando a verticalização da produção, tendendo para a monopolização do setor ao realizar fusão com empresas de distribuição e exibição em todo o território norte-americano.

Entretanto, os exibidores americanos, preocupados com a sua dependência potencial de apenas um fornecedor, se uniram nesse período para constituírem a First National Exhibitor's Circuit. E abriu-se novamente um período de integração horizontal reforçada e sistemática, com Chaplin se unindo a Pickford, Fairbanks e Griffith para criarem a United Artists. Em represália, a Paramount também procurou aprofundar sua verticalização (MUSSER, 1997, p. 67). O esforço da Paramount em expandir seu domínio no mundo, multiplicado por sua participação na Primeira Guerra, estimulou a criação de um novo sistema de produção de entretenimento massivo, que entronou todas as tendências de pacificação do público de cinema: a indústria do cinema hollywoodiano clássico.

\section{Visões da Militância francesa sobre o Cinema: a escala dos de baixo}

A afirmação de Vanessa R. Schwartz de que a flânerie está na gênese do público moderno é factível, e importante de ser destacada. Entretanto, o espectador cinematográfico não está contido na multidão como necessidade. 0 argumento processual da formação do público moderno perde a perspectiva 
histórica com esse procedimento que visa à estrutura. O caráter da reprodutibilidade do filme não deve caracterizar a forma com que o público percebe e participa do espetáculo cinematográfico; esse caráter define apenas um mercado de massa, normalmente apresentado a uma multidão, aspectos destacados em relação ao caso norte-americano e ao caso francês para observar o surgimento do mercado cinematográfico.

A fruição do filme, por outro lado, historicamente foi realizada das mais diversas formas, sem renunciar à coletividade, essa sim natural ao espetáculo cinematográfico. Não foram nulas as tentativas - relativamente bem sucedidas - que não se caracterizaram pela presença de uma "multidão" na relação do público com o espetáculo. Da mesma forma, a presença da "massa" na relação de produção e distribuição fílmica não é uma característica natural ao processo cinematográfico, se tomarmos a trajetória de alguns militantes franceses do começo do século XX que lançaram mão do uso da projeção, e da produção cinematográfica, em experiências como a do Cinema do Povo.

A questão parece irrisória, se colocada diante do vasto domínio que o cinema comercial clássico veio a ter a partir de 1914, reiterando a relação majoritária do público com o filme enquanto espectação de massa e passiva. As tentativas de enfrentamento dessa configuração da instituição cinema, entretanto, não surgiram de meras vontades individuais de militantes que, por acidente, se encontraram com o cinematógrafo. A extensão que o movimento operário tomou com os sindicatos e com as Bolsas de Trabalho, e as experiências de mobilização e enfrentamento desde a Comuna, proporcionaram visão social e cultural ampla do campo de luta da militância no período do pré-guerra.

O movimento operário francês, pela influência dos sindicalistas revolucionários, lançou mão da estratégia de greve geral a partir do final do século XIX, com recusa de mediação do Estado e com ataque direto aos empregadores. Tal estratégia foi expandida pela Confederation Genérale du Travail (CGT), que assumiu essa posição ampliada no movimento operário a partir de 1906. As greves resultavam quase sempre em fortes enfrentamentos, tanto nas ruas quanto no campo ideológico. A cultura do enfrentamento - que se perfazia das recentes memórias de 1848 e 1871 - se mantinha, ainda que 
reformulada nos diversos campos de luta e de representação do movimento. 0 movimento deveria estar atento, então, à propaganda e à representação cultural do inimigo de classe.

Os primeiros anos de cinema se caracterizaram entre os militantes, por exemplo, pelas reservas a respeito dos lazeres populares e do cinema. Fernand Pelloutier, na conferência "A arte e a revolta", de 30 de maio de 1896, expressa essas reservas ligando o álcool, os espetáculos e o bordel à falta de liberdade de espírito necessária à mobilização para as revoltas. Os filmes ligados à corrente dos Incoerentes - movimento artístico libertário do final do século XIX e que influenciou George Méliès e Émile Cohl - e os espetáculos revolucionários eram minoria em relação às grandes produções que tratavam os trabalhadores e os movimentos sociais por meio de estereótipos que os inferiorizavam ou os ridicularizavam.

Isabelle Marinone mostra que a Gaumont, por exemplo, com o Scènes de la vie telle qu'elle est, associava o líder sindicalista e os militantes a indivíduos ridículos ou trágicos, quase sempre bêbados imprudentes. Nesse sentido, conforme sentença de Pelloutier, a arte em geral "se faz serva, cúmplice da sociedade burguesa", e essa era a percepção inicial que os anarquistas deveriam demonstrar sobre o cinema. No jornal Le Libertaire - tradicional semanário anarquista, dirigido por Sébastien Faure - de 27 de maio de 1911, Émile Guichard, militante revolucionário que atuava no mundo artístico, teceu várias críticas que resumem bem a visão dos militantes do movimento operário em geral sobre o cinematógrafo:

Não há nada mais repugnante do que as cenas que se desenrolam sob os olhos do público. O patriotismo, o respeito às leis, todas as virtudes burguesas são lá exaltadas. Por vezes, é um bravo soldado, cujos filmes mostram-nos as proezas sanguinárias, que retorna ao país coberto de condecorações e de uma explosão de aplausos. [...] Mas olha, não vê que esses 'exibicionistas' te embrutecem? [...] Aqui, pegue a greve, veja como apresentam os trabalhadores que nela se revoltam; o 'líder', sem dúvida um delegado da CGT, arengou na apresentação precedente no bar, e pagou bebida a trabalhadores honestos... [...] (GUICHARD, 1911, tradução nossa). 
E prossegue com a descrição dos estereótipos retratados no cinema:

São pequenas comungantes, alegres em comer em suas vestes brancas; uma de suas companheiras não pôde se aproximar da mesa santa, ela está doente, morrendo. Não temas, o bom padre de cabelos brancos vem trazer-lhe a hóstia consagrada e, o que a ciência não pôde fazer, a religião faz: a pequena bela comungante é salva. Aplaudam, ralé! [...] Bela educação para as crianças e para os adultos! A viagem pelos cinemas forma a juventude, ensinam divertindo... O que você diz, ralé? [...] Camaradas, boicotemos os cinemas que sabotam nossas ideias, obriguemo-los, por todos os meios, a mudar seu gênero de espetáculos; assim como o teatro, o cinema deve educar e não embrutecer (GUICHARD, 1911, tradução nossa).

O incômodo com o cinema, apesar das condenações expressas de determinados militantes, parece dividir quase sempre um espaço com a percepção paralela de que o novo meio também era uma boa ferramenta de educação e propaganda. Nota-se que esse texto de Guichard para o Libertaire, afinal, era uma repercussão da primeira sessão de que o militante Gustave Cauvin havia participado como conferencista com o uso do cinematógrafo, no dia 13 de maio daquele ano, ao lado do médico Legrain, ocasião a qual Guichard apresentou seu apoio e finalizou com os dizeres sobre a função educativa do cinematógrafo.

Numa outra nota do La Bataille Syndicaliste - jornal diário, ligado a CGT de fevereiro de 1914, temos uma interessante descrição da reação contrária do público com os filmes patrióticos:

Numa dessas noites, no Cinema Excelsior situado na Avenida da República, um público numeroso assistia passar sobre a tela as atualidades da semana. De repente, por volta das nove e meia, projetou-se um filme apresentando Roland, o cornetista preguiçoso de Sidi-Brahim. Assobios eclodiram. Enquanto Poincaré, e depois Noulens desfilavam sobre a tela, gritos: "Hou! Hou! Os três anos!" "11 ressoavam na sala. Unanimemente, os espectadores vaiaram o carnavalesco desfile patriótico. Nesse momento, o diretor do cinema tomou a palavra e ameaçou os manifestantes de lançá-los porta a fora. Esse diretor esquece que, se o direito de aplaudir existe, sua contrapartida deve igualmente existir. Se ele conta apenas com o público chauvinista, pode fechar a loja (FAIT..., 1914, tradução nossa).

\footnotetext{
${ }^{11}$ Em referência à lei da obrigatoriedade do serviço militar de três anos, instituída na França no pré-guerra e ferozmente combatida pelos movimentos sociais.
} 
Outro fator de afastamento do movimento operário em relação ao cinema foi a alegada delação policial. Segundo relatos em jornais, o cinema teria passado a ser utilizado extensamente pela polícia para o registro das manifestações, a partir de 1910, como forma de identificar os militantes. Em 1911, os militantes da Champanha em Marne denunciavam esse uso pela polícia contra o movimento:

Sabia-se mesmo que esses repórteres não se faziam de rogados para transmitir suas imagens para a polícia; mas o que não sabíamos, é que os filmes cinematográficos serviam de agentes indicadores. Nada mais fácil: sob o pretexto de filmar para divertir - público, toma-se a fotografia dos fatos e gestos dos manifestantes, constituindo assim provas irrefutáveis (DAUTHUILLE, 1911, tradução nossa).

A prática do uso de imagens pela polícia não seria nova. Marinone destaca que a criação de arquivos fotográficos na época da Comuna teria sido enriquecida com o cinema no começo dos anos 1910, chegando a estabelecer inclusive uma instituição de controle por meio do cinema. Segundo a autora, um dos exemplos marcantes foi a revolta dos viticultores em abril de 1911, em que a máquina judiciária, exercendo uma severa repressão apoiada pela presença de um exército composto de 40 mil homens, envolveu o cinema na denúncia. No dia 24 de abril daquele ano, os membros do grupo de Reims, autoridades, o comissário de segurança e vários policiais examinaram os filmes Une charge de cavalerie (Uma revista de cavalaria), L'Insulte à l'armée (O insulto ao exército) e Le pillage de la Maison Gauthier (A pilhagem da casa Gauthier) que, projetados em velocidade reduzida, teriam permitido identificar os elementos suspeitos da revolta que se passara no dia 12 de abril (MARINONE, 2009, p. 46).

Em editorial da edição do dia 21 de janeiro do Ciné-Journal, com o título Le Cinématographe et la Police, o então editor e um dos principais empresários do meio cinematográfico francês, Georges Dureau, havia escrito: "Vocês sabem que o cinematógrafo é, foi, e será o auxiliar da ciência, da educação, da arte, da guerra, do progresso em geral e de tudo em particular. Não devemos agora transformá-lo em agente da Segurança?” (DUREAU, p. 3, 1911, tradução nossa). No final de abril, após o caso da revolta dos viticultores, o próprio Dureau temia o uso do cinema pela polícia após entrevista com sindicalistas da CGT. Na 
Quando o mal é grande e sem remédio radical, tomamos remédios improvisados - a industrialização do cinema e as origens da organização do público na França (1895-1914)

Luiz Felipe Cezar Mundim

entrevista, os militantes denunciavam o acontecido em Reims e faziam o alerta em tom de ameaça para o que poderia acontecer com as aparelhagens, e com os próprios operadores durante as manifestações, caso estivessem presentes.

Apesar da omissão, e das reservas dos anarquistas em relação ao cinema no período entre 1895 e 1908, a ideia de um cinema com virtudes "educadoras" já se formava aos poucos no espírito do movimento operário. As experiências de exibições com finalidade educativa ou para propaganda, como foram os casos das Universités Populaires e as Bolsas de Trabalho, se fizeram presentes e tenderam a se multiplicar no final desse período ${ }^{12}$.

Paralelamente, estava a importância dada à educação pelos anarquistas. A necessidade revolucionária, dizia Jean Grave (1893), consistiria antes de tudo em preencher de ideias a cabeça dos indivíduos. Baseado nas ideias que Proudhon e Bakunin tinham para a educação (fundamentadas na perspectiva da instrução integral - científica e prática), Paul Robin foi quem primeiro executou a ideia de educação integral, mista e universal. O esforço de Robin, concretizado no Orfanato Cempuis, foi o de criar uma formação de vida pela prática do ensino, o que atualmente denomina-se "métodos ativos".

A experiência de Sébastien Faure a partir de 1904 na França, com a criação da escola La Ruche para órfãos e crianças pobres, em que o objetivo era o apreço pela vida popular, teve como premissa o aprendizado fora da escola. Conforme percorremos as cartas e materiais de divulgação do orfanato, dentre os quais

\footnotetext{
12 Embora não fossem exatamente organizações dos trabalhadores à época, as Universités Populaires tinham grande apelo e capilaridade social e por todo o movimento operário. Fundadas em 1899, e dedicadas a oferecer todas as possibilidades de educação, as Universités Populaires desde cedo lançaram mão das projeções, sendo que as cinematográficas devem ter se iniciado em 1906, ano do primeiro registro que encontramos de uma sessão com o uso do cinematógrafo (Cf.: Les Cahiers de l'Université Populaire. Revue mensuelle. 10 mars 1906). Durante o congresso de 1910, segundo Lucien Mercier, os membros se interrogaram acerca da contribuição que o cinema poderia dar à educação do povo. Apesar do prog-nóstico pessimista e depreciativo, a representação da Université Populaire La Fraternelle de Saint-Claude, ao anunciar a instalação de um cinematógrafo na Maison du Peuple daquela cidade, se mostrou otimista, e declarou o objetivo com as exibições nas seguintes palavras: "O cinema é objeto de desejo comum; contudo, estamos assustados diante da mediocridade dos meios que utilizam esse aparelho em uma noite de educação popular. Os temas científicos e atrativos poderão, entretanto, ser encontrados e fornecer ao menos um abrandamento instrutivo." (MERCIER, 1986, p. 167-168). Para as atividades das Bolsas de Trabalho com o cinematógrafo ver, por exemplo: ARCHIVES NATIONALES. AN F713338: Ardennes - Agitations contre la loi de 3 ans; Aisne Agitations contre la loi de 3 ans; Cinéma populaire de la Bourse du Travail de Saint-Quentin. Pierrefite-sur-Seine, 1912. Relatórios e cartazes. Série F/7 Police Générale.
} 
conferências proferidas em diversas cidades, notamos que a educação deveria se dar na rua, na oficina, nas barracas de feiras, e no "mundo ambulante"13. Esses modelos pedagógicos constituíram exemplo e inspiração para as primeiras experiências do movimento operário com o cinema, que se iniciou efetivamente a partir de 1911, com projeções ambulantes realizadas por militantes como o já mencionado Gustave Cauvin.

O ano de 1913 foi fértil nesse sentido. O movimento operário experimentou as marchas de Gustave Cauvin com o cinematógrafo; sindicatos e bolsas de trabalho comprando seus próprios aparelhos cinematógrafos no interior do país, e a criação do Cinema do Povo no segundo semestre. No começo de 1913, a ideia desse cinema para o movimento operário parecia demonstrar seu amadurecimento e extrapolar a perspectiva de exibição de filmes não apenas como ferramenta de educação infantil ou de propaganda. Um artigo publicado no La Bataille Syndicaliste é particularmente interessante. Em Le Public et le Cinéma, de 4 de março de 1913, a preocupação maior do texto era, para além do conteúdo dos filmes exibidos, com a organização em si de uma sessão de cinema, o que não era possível em um ambiente comercial. A reprodução integral do artigo é relevante:

Não seria demasiado repetir que atualmente os filmes nos cinemas visam apenas a escravizar mais os trabalhadores. Eles são, com o concerto musical (que tendem a substituir), fatores da dominação capitalista. Os escravizados dos escritórios e das fábricas, que vão se distrair por um instante quando a jornada acaba, não encontram lá nenhum ensinamento. Alternando cenas sentimentais idiotas, veem desfilar sobre a tela apenas filmes governamentais. O povo aprende, assim, a venerar os seus mestres - presidente, ministros, o exército, a polícia, todos os poderes que o esmagam.

Nada de bom pode-se esperar do cinema comercial. Apesar do gosto do público, os diretores dos estabelecimentos cinematográficos, todos reacionários, impõem filmes em que a insanidade compete com o grotesco.

O diretor do cinema Ramey, para citar apenas um entre cem, veio dar a medida do seu saber-fazer.

\footnotetext{
${ }^{13}$ Para documentação mencionada, entre cartas, materiais de divulgação e relatórios de vigilância policial sobre a escola La Ruche, ver: ARCHIVES NATIONALES. AN F715954/r: Direction de la Sûreté Générale - Dossier Sebástien Faure. Série F/7 Police Générale. Pierrefite-sur-Seine, $\mathrm{s} / \mathrm{d}$.
} 
No último 30 de outubro, ele contratou para a sua sala o tenor Clovis d'Aubinel, muito conhecido nos grupos socialistas, onde canta um repertório humanitário. Começou, então, sexta passada. Foi precedido no programa por um filme em louvor ao nosso Poincaré nacional. A "Lorrain" aparecia num carro em meio aos tubarões queridos da nossa bela República. Tudo acompanhado da Marselhesa.

Uma saraivada de assobios acolheu o aquário governamental. Chegou a vez do camarada d'Aubinel. De uma bela voz nuançada, ele detalhou duas canções intituladas: Vous ne voyez donc pas? e Demain, que despertaram o entusiasmo do público. Crepitaram inúmeros Bravos!. Perplexo e furioso, o diretor desceu correndo as escadas e deu a ordem para fechar a cortina sobre o artista, sem sequer dar-lhe tempo de agradecer o público caloroso.

"Que audácia cantar músicas como essas!" Resmungou.

Na saída, o diretor do cinema Ramey disse a Clovis d'Aubinel:

"A sala está ultrajada com as suas canções. Vou pagá-lo esta noite, mas não volte mais."

Inúmeros espectadores, tendo ouvido essas palavras, fizeram ouvir os seus próprios protestos: "Nós assobiamos para o seu filme, mas ainda queremos ouvir esse artista que não foi contratado por você, diretor, mas sim por nós, o público."

O diretor, compreendendo que ele cometera um erro ao tentar impor o seu próprio ponto de vista, voltou atrás com a sua decisão: - Certo! Venha cantar amanhã.

- Ótimo! Amanhã, cantarei: A guerra... é a miséria, respondeu d'Aubinel.

Se o público manifestasse mais frequentemente a sua vontade, os diretores de music-hall e de cinema seriam obrigados a renunciar os absurdos patrióticos ou obscenos (LE PUBLIC..., tradução nossa).

O texto, por si só, descreve bem o processo de tomada de consciência dos aspectos ideológicos do cinema comercial. A partir disso, sua superação se dá pela ocupação da própria sala de cinema, cabendo ao povo tomar a sessão de assalto, e realizar o que bem entende na sua relação com a sessão cinematográfica. O povo, aqui, é também o público, dotado de todas as suas capacidades de discernimento e posicionamento diante do evento cinematográfico.

Os artigos problematizando o cinema comercial continuam a aparecer, e apenas cinco dias depois, Marcel Martinet publica o texto Le cinéma nécessaire, também no La Bataille Syndicaliste, comentando esse último artigo do dia quatro. Martinet constata o problema reconhecendo o papel que o cinema já ocupava na vida do trabalhador, e lança questões que ilustram bem a disseminação do cinema pela cidade: 
Bons motivos não faltam para desviar-se para o bar, um amigo cansado da sua jornada de trabalho. Mas, numa noite em que não está muito exausto, se ele quer pagar uma distração a sua esposa e filhos, onde levá-los? Pode haver um concerto na Rua GrãBretanha, ou uma apresentação organizada por camaradas em Montmartre, mas, isso vai render-lhe uma boa caminhada se morar em Vaugirard, ou no 120; e também, Roudine o reconhece, o cinema é divertido, vivo. Eles vão ao cinema do bairro. Nós vamos impedir isso? Devemos privá-lo dos pequenos prazeres que nossos chefes the permitem? E podemos assim fazer? (MARTINET, 1913, tradução nossa).

Martinet destaca ainda que, para o sucesso de uma greve do público, demandando a reforma dos espetáculos, seria necessária uma longa ação, o que seria impossível. O problema, então, se deslocaria para os militantes. Apesar de reconhecer que o cinema não seria uma "arte elevada", os militantes deveriam eles mesmos tomar o cinema como remédio para combater o cinema comercial:

Não existem duas saídas. Falei muito disso para ter que afirmar que não considero o cinema como uma forma de arte elevada; mas, quando o mal é grande e sem remédio radical, tomamos remédios improvisados; deve-se combater o mal por ele mesmo, opor ao cinema imundo o nosso cinema. É possível. Em cada bairro, ou ao menos em cada distrito, deve-se fazer o cinema vermelho diante dos incontáveis cinemas amarelos; é mais certo e, se tal empresa parece difícil agora, terá sido mais fácil do que avermelhar progressivamente os cinemas amarelos (MARTINET, 1913, grifo do autor, tradução nossa).

Nota-se, assim, que a ideia de um cinema militante estava sendo forjada. Se antes, apenas de maneira informal e empírica, naquele momento o impulso intelectual também tomava forma. O que procuramos destacar, retomando esses poucos aspectos do movimento operário francês do começo do século XX e sua posição diante do cinematógrafo, é que a criação da indústria do cinema não foi sentida de forma passiva e por uma população que, "inocentemente", apenas caminhava pelas ruas nas suas poucas horas de descanso, em busca de lazer e entretenimento.

A vivência, e a convivência social dos trabalhadores nos primeiros anos de existência do cinema - fossem elas pela interação com os espetáculos nos Théatrês, Music-Halls e nos nickelodeons, ou pela busca solidária por outra apropriação da projeção cinematográfica e da própria representação fílmica -, 
apresentaram alternativas à relação com a imagem em movimento, diversa da comercial que se direcionou à domesticação e pacificação dos indivíduos. A vivência dessa mudança, orientada à domesticação e à dominação, compunha elementos de uma experiência específica, reelaborada criticamente pelos discursos nas publicações de jornais, apontando para a pretensão de se transformar em cultura, por meio da apropriação do novo modo de representação na forma de um cinema militante.

Para essa cultura nova, desenvolvida pelos trabalhadores e exposta pelo movimento operário francês nos anos de 1910, ao historiador faz-se necessário uma abordagem em escala alternativa na história da relação entre as pessoas e os filmes, na medida em que a passividade diante do espetáculo não é natural à experiência cinematográfica. Essa escala alternativa tem como base a ideia de público. Nela, as pessoas e as suas trajetórias, bem como as coletividades, organizadas ou engajadas na sua relação com os filmes, podem revelar nuanças históricas relevantes para o entendimento desse fenômeno definitivo da modernidade que é a representação da realidade pela imagem em movimento.

Talvez nos tempos atuais possamos falar até em um público total, em que a relação entre as pessoas e a imagem em movimento se dá do despertar ao adormecer, em que essa relação se afirma como mecanismo de uma das principais formas de atuação e de vivência na realidade política e cultural. Esse pressuposto, que poderia constituir uma hipótese, pode ajudar a perceber no público o aspecto alternativo de escala na história. Todos somos o público na atualidade, e nem por isso somos meros espectadores. As possibilidades de atuação de indivíduos e grupos nas mídias e redes sociais está dada. O impacto dessa ação, por outro lado, ainda se encontra em aberto, podendo vir a constituir incontáveis modos de representação audiovisuais, que não apenas o que foi criado pelo cinema comercial ao longo do primeiro cinema. 


\section{Referências}

ADORNO, T. W.; HORKHEIMER, Max. Dialética do esclarecimento: fragmentos filosóficos. Rio de Janeiro: Jorge Zahar Ed., 1985.

ALTENLOH, Emilie. Pour une sociologie du cinéma (1914). In: BANDA, Daniel; MOURE, José. Le cinema: naissance d'un art - 1895-1920. Paris: Éditions Flammarion, 2008.

ARCHIVES NATIONALES. AN F715954/1: direction de la surete generale: dossier Sebástien Faure. Pierrefite-sur-Seine, [19--]. Série F/7 Police Générale.

DE AMICIS, Edmondo. Cinématographe Cérébral. In: BANDA, Daniel; MOURE, José. Le cinema: naissance d'un art - 1895-1920. Paris: Éditions Flammarion, 2008.

BANDA, Daniel; MOURE, José. Le cinema: naissance d'un art: 1895-1920. Paris: Éditions Flammarion, 2008.

BRENEZ, Nicole. O cinema e o "uso das representações". In: MARINONE, Isabelle. Cinema e anarquia: uma história "obscura" do cinema na França (1895-1935). Rio de Janeiro: Azougue Editorial, 2009.

BURCH, Noel. La lucarne de l'infini: naissance du langage cinématographique. Paris: L'Harmattan, 2007.

COSTA, Flávia Cesarino. Primeiro Cinema. In: MASCARELLO, Fernando (org.). História do cinema mundial. Campinas: Papirus, 2006. p. 17-52.

DAUTHUILLE, A. En Champagne - Cinéma-Police. Le Libertaire, Paris, 29 abr. 1911.

DUREAU, Georges. Le Cinématographe et la Police. Ciné-Journal, Paris, p. 3, 21 janvier 1911.

ESQUENAZI, Jean-Pierre. Sociologia dos públicos. Porto: Porto Editora, 2006.

FAIT divers: films patriotiques. La Bataille Syndicaliste, Paris, 22 fevrier 1914.

GRAVE, Jean. La Société mourante ou l'anarchie. Paris: Tresse \& Stock Éditeurs, 1893.

GUICHARD, E. Au Cinéma. Le Libertaire, Paris, 27 mai 1911. 
HERZOG, Charlotte. The movie palace and the theatrical sources of its architectural style. In: HARK, Ina Rae (org.). Exhibition, the film reader. Londres: Routledge, 2002.

LAURENT, E.; LEPINE. Extrait de l'ordonnance de Police Concernant les Theatres (Cinématographes). Paris, le 10 Août 1908. In: Cinéma: Annuaire de la projection fixe et animée. Paris, Charles-Mendel Editeur, p. 52, 1911.

LE PUBLIC et le cinema. La Bataille Syndicaliste, Paris, 04 mars 1913.

LEVI, Giovanni. Comportamentos, recursos, processos: antes da "revolução" do consumo. In: REVEL, Jacques (org.). Jogos de escalas: a experiência da microanálise. Rio de Janeiro: Fundação Getúlio Vargas Editora, 1998. p. 203-224.

MACEDO, Felipe. Cinéma du Peuple, le premier cinéclub. The cineclub's review: n. 1. Marília: Editora Praxis, 2010.

MARINONE, Isabelle. Cinema e anarquia: uma história "obscura" do cinema na França (1895-1935). Rio de Janeiro: Azougue Editorial, 2009.

MARTINET, Marcel. Le cinema nécessaire. La bataille Syndicaliste, Paris, 09 mars 1913.

MAUERHOFER, Hugo. A psicologia da experiência cinematográfica. In: XAVIER, Ismail (org.). A experiência do cinema. Rio de Janeiro: Graal, 1983.

MCDONALD, D. Association Bulletin n. 14. Executive Committee meeting. In:

Views and film index. New York: Films Publishing Co, n. 106, May 2, p. 5, 1908.

MENOTTI, Gabriel. Arquitetura da espectação: a construção histórica da situação cinema nos espaços de exibição cinematográfica. Revista Eletrônica do Programa de Pós-Graduação em Comunicação da Universidade Federal Fluminense, Rio de Janeiro, Ano 9, n. 18, p. 1-12, jul. 2007.

MERCIER, Lucien. Les universites populaires: 1899-1914: éducation populaire et mouvement ouvrier au début du siècle. Préface de Madeleine Rebérioux. Paris: Collection Mouvement Social; Les Éditions Ouvrières, 1986.

MORETTIN, Eduardo V. O cinema como fonte histórica na obra de Marc Ferro. In: CAPELATO, Maria Helena et al. História e cinema: dimensões históricas do audiovisual. 1 ed. São Paulo: Alameda Casa Editorial, 2007. p. 39-64.

MUNDIM, Luiz Felipe C. As marchas de Gustave Cauvin: a primeira forma sistematizada e regular do cinema militante. Revista Mundos do Trabalho, [S.l.], v.9, p. 83-98, 2018. 
MUSSER, Charles. L'industrie du cinema em France et aux États Unis entre 1900 et 1920: l'évolution du mode de production. In: BENGHOZI, Pierre-Jean; DELAGE, Christian. Une histoire économique du cinéma français: 1895-1995: regards franco-américains. [Paris]: L'Harmattan, 1997. p. 63-80.

NORRIS, Frank. McTeague: a story of San Francisco. New York: Double Day \& Company, 1904.

PERRON, Tangui. Le contrepoison est entre vos mains, camarades': C.G.T. et cinéma au début du siècle. Le Mouvement Sociale, Paris: Éditions de l'atelier, $\mathrm{n}$. 172, p. 21-36, juil./sept. 1995.

RANNEY, H. M. Account of the terrific and fatal riot at the New-York Astor Place Opera House: on the night of May 10th, 1849. New-York: H. M. RANNEY, 1849.

REVEL, Jacques. A história ao rés-do-chão. In: LEVI, Giovanni. A herança imaterial: trajetória de um exorcista no Piemonte do século XVII. Rio de Janeiro: Civilização Brasileira, 2000. p. 7-37.

SCHWARTZ, Vanessa. O espectador cinematográfico antes do aparato do cinema: o gosto do público pela realidade na Paris fim-de-século. In: CHARNEY, Leo; SCHWARTZ, Vanessa R. (org.) O cinema e a invenção da vida moderna. São Paulo: Cosac \& Naify, 2001. p. 411-440.

WHAT PATHÉS visit means. In: Views and film index. New York: Films Publishing Co, n. 106, May 2, p. 3, 1908.

YOUNG, Paul. Telling descriptions: Frank Norris's kinetoscopic naturalism and the future of the novel, 1899. In: MODERNISM / MODERNITY. [Baltimore]: The Johns Hopkins University Press, 2007. v. 14. p 645-668. 